\title{
The Role of Brand Authenticity on Brand Equity of Football Clubs with the Mediating Role of Brand Personality
}

\author{
${ }^{1}$ Akbar Mohammadi Argi, ${ }^{1}$ Mohammad Ehsani*, ${ }^{1}$ Rasoul Norouzi Seyed Hossini, \\ ${ }^{1}$ Marjan Saffari \\ ${ }^{1}$ Department of Physical Education, Faculty of Humanities, Tarbiat Modares University, Tehran, Iran.
}

Submitted 01 August 2020; Accepted in final form 06 October 2020.

\begin{abstract}
Background. The brand equity is raised as one key subject in founding the value creation for the brand. Nowadays, the sports managers are searching for creating a very powerful brand and favorable for their own organizations obtaining one long term and highlighting the consumers' athletic experiences and the continuous relationship with them. Objectives. The purpose of this study was to focus on the role of brand authenticity with the mediating role of brand personality on the brand equity of Persepolis Club. Methods. In this regard, a descriptive research method of survey was used. The statistical population of the present study consisted of all spectators of Persepolis team. In this study, the available sampling method was used and the sample consisted of 410 fans of Persepolis Club. The Instrument used in the present Research is three questionnaires of brand authenticity, brand personality and brand equity, all of which have validity and reliability. In order to investigate the direct and indirect effects of brand authenticity on brand equity, Structural Equation Modeling (SEM) was used. Results. The research findings showed that brand authenticity affects brand equity (0.67) and brand personality (0.54). Brand personality affects brand equity (0.34) and brand personality mediates the relationship between brand authenticity and brand equity (0.12). Conclusion. Based on the results, it can be concluded that the managers of Persepolis Club should increase the brand authenticity by establishing the club museum as well as the club store and planning on the unique features of the club, such as the number of champions, the large fan community, etc., and thus increase their brand equity.
\end{abstract}

\section{KEYWORDS: Brand Authenticity, Brand History, Uniqueness, Brand Personality, Football.}

\section{INTRODUCTION}

The brand equity is raised as one key subject in founding the value creation for the brand (1). Nowadays, the sports managers are searching for creating a very powerful brand and favorable for their own organizations obtaining one long term and highlighting the consumers' athletic experiences and the continuous relationship with them. In this regard, the brand management literature supports this matter that the brand equity will rest to a large extent on the customer's identity-company (2) and in the sport, the effects of fans' identity into one team and on the brand equity has been taken into consideration well (3). Accordingly, and based on this matter and identity and the sports team's fans' strong connection with their own team, we see that many teams such as Chicago Bears, Manchester United and also the sports leagues including the UEFA Champions League (Union of European Football Associations) and the National Basketball League in Australia all have applied for re-branding (4). In the past, the sports teams and leagues were of

*. Corresponding Author:

Mohammad Ehsani, Professor

E-mail: ehsani@modares.ac.ir 
a very exclusive position in attracting the fans and aficionados but the competition for absorbing the sports consumers has increased after the increase of sports institutions and new media. The sports teams and leagues are now competing with the other spending leisure time options including festivals, cinemas, restaurants, camps, travel tours and so forth on the money which is paid by the customers for entertainment. On the other hand, the professional sport has accepted a more commercial approach and for this reason, making a very powerful brand and then distinguishing and differentiating the same from the rivals has changed to a more vital subject matter for the sports teams and leagues (5).

So, and in terms of expressions, one brand name can be defined as any determined sign for differentiating the products of one company from the other rivals (6). On the other hand, the concept of brand equity from the customer's view point (CBBE=Customer-Based Brand Equity) is the different effects which the brand knowledge leaves on the customers' reactions towards the marketing activities and regarding the same brand. Since such expression emerged in the 1980s therefore the brand value has drawn more attention among the marketing specialists and researchers. The customer -based brand equity is a multi-dimensional concept and one interwoven phenomenon (7). Every brand can be of a higher equity when the customers show a very acceptable and favorable reaction into the products and the entire marketing activities of that brand. Consequently, enjoying a brand with the higher equity may cause the customers show a better reaction towards the brand expansion strategies, have some less sensitivity and obsession into the prices increase, go and search for finding their own favorable brand in the distribution networks and department stores and or they may regularly keep on buying and using the foregoing brand even in case of the advertising activities failure. On the other hand, those brands with the negative equity will face with the customer's unpleasant and unacceptable reaction into the marketing activities (8). The brand equity is a value added that a product makes it through a brand. The brand equity is considered like a property for a company which can increase the business cash flow namely one multidimensional concept which can increase by reinforcing its dimensions. These dimensions are the knowledge, perceived quality, loyalty, association and the total brand equity (9). The brand knowledge is the ability to detect (Recognition) and recalling the potential purchasers concerning one trade mark as a member for a special category of products. The customer-based brand equity is made when the consumers keep in their mind a higher level of knowledge and acquaintance with that brand and also some exclusive, favorable and powerful associations (10). The perceived quality is the consumer's overall judgment on the product superiority or service which is derived from the combination of consumers' expectations and understanding (11). Creating the loyalty among the customers is a concept that has been already taken into account more than ever in the modern businesses because the loyal customers have changed to the main component of organizational success (12). Aker has also defined the brand loyalty as the customer's dependency and attachment to the brand. The brand association is the information nodes connected to the brand in the mind which can make the trade mark meaningful for the consumer and also the brand association can present the truth that has been formed regarding the brand in the consumer's mind (9). Studying the research literature will explicitly suggest that the brand equity should be as an important part of the scope of marketing research in every company because it summarizes the important variables of consumer behavior such as brand loyalty, perceived quality, brand awareness and brand associations (13). In the research literature, it has been regularly discussed (14-16) that the ideal brand equity lead to increases the probability of brand selection, customer retention (and retailers), profit margins, willingness to pay high prices, customer search, the effectiveness of marketing communications, positive word of mouth advertising, brand licensing opportunities, and brand development. Brand equity also reduces the vulnerability of competitive marketing actions as well as price sensitivity (17).

In recent decades, professional sport has emerged as a lucrative industry that provides a variety of business opportunities and situations. Sports managers are moving towards that consider their teams as brand and brands which need to be managed. One of the goals of sports teams is to create a strong brand so that such 
brand can influence the behavior of real and potential customers of that team (18). Branding is known as an influence strategy for sports organizations both domestically and internationally and is one of their most important assets. It is fair to say that branding is the newest game in the sports industry. A sports team has such potential to build what is called brand equity, which is created through investment and attention to the emotional relationship with fans (19). Numerous factors may influence the selection of a brand from among different brands and the amount of perceptual value of consumers of the brand and finally cause the brand equity. One of these factors is brand authenticity. Brand researchers often consider the authenticity as a key source for promoting a brand's competitive advantage, especially in times of distrust.

Gupta et al. (2010) stated that a positive attitude towards the brand creates a positive brand response to the impact of customer's purchase activity (20). Those authentic and original brands define the values or equity that direct brand behaviors and reactions in the market and have a strong impact on the customer's attitude towards the brand which in turn will increase the trust that leads firms and companies to commercial success. Also, Torabi (2016) stated that brand authenticity affects the choice of products through four dimensions of brand equity (21). Romiani (2018) also expressed in his research that brand authenticity increases the loyalty of sports watchers through influencing the brand equity (22). The results of research indicate that managers shall pay attention to brand authenticity because it builds brand trust (23). Brand authenticity is loyalty to the promises and commitments of the brand. The personality and whatever are related to the destination brand must be real and have reasonable support. Innovative branding requires proper marketing and smart investment in facilities and services. Without investment and development of unique services and features, the core of the brand will not be reinforced and brand loyalty and repeat purchases will not be achieved (24)). Kadiro (2010) has identified seven key dimensions to brand authenticity which these seven dimensions include real-fictitious, scale, extreme performance, being commercial, being unique, rich history, community, and empowerment (25). On the other hand, one of the variables that can directly and meditatively affect on brand equity and ultimately consumer behavior is brand personality. Aker defines brand personality as a set of human characteristics related to a brand. In fact, the concept of brand personality derives from the concept of human personality; where the people communicate effectively and stably with the brand through attributing personality traits to brands and expressing their ideal and true selves via the brand (26). Consumers use the dimensions of brand personality as a determinant of brand added value. Today, it is well defined that brands with a distinctive and strong personality are easily distinguished from competitors or rivals. Brand personality can also be used as a benchmark for positioning and can be effective in developing brand equity. The totality of the brand personality affects the consumers' purchase behavior and attitude towards the brand when strongly activated in their minds (27). Researchers, who have studied in the field of consumers, have found that companies having strong brands and positive brand personalities, achieves countless benefits. The brand personality of sports teams from the viewpoint of Tsiotsou (2012) consists of five dimensions: 1. Competitiveness 2. Prestige 3. Authenticity 4. Moral Orientation 5. Credibility (28).

An ideal brand personality has many benefits: strengthening consumer preferences, increasing emotions in consumer, increasing the level of trust and loyalty, and providing a basis for product differentiation. As a result, when brand personality and customer are consistent, consumers can be expected to be consistent in their purchasing behavior (29).

Marilyn Giroux et al. (2017) stated that consumers consider brand personality while studying and reacting to the advertising strategies. In fact, the compatibility between brand personality and the selected marketing strategy positively affects consumer perceptions and brand equity (30). Freling et.al. (2011) also stated that a strong, unique and desirable understanding of brand personality can lead to a set of unique and appropriate brand images, as a result, it creates the potential capacity in order to influence the total brand equity (31). Papadimitriou et.al. (2019) declared that brand personality positively and significantly affects the attitudinal loyalty of fans (32). Shahzad et al. (2018) also stated that brand personality mediates the relationship between 
brand experience and brand equity, which shows that brand personality can affects the brand equity as a mediator (33). Considering the importance and stand of the consumer in the market, customer acquisition and retention can be accounted as one of the most important issues in marketing activities in brand valuation (goods and services). Given the above-mentioned topics, it can be said that brand authenticity and brand personality are two components that can affect the brand equity. An issue that is considered in such research is the importance of the brand and its special equity for football clubs in the new era and its optimal utilization. As the research literature shows, brand originality and personality are two components that affect the brand equity. Persepolis Club, given its history, as well as having millions of fans in Iran and some neighboring countries, and ultimately the ability to compete and its highest level and prestige, it has a brand originality and personality which it can enhance the brand equity, but unfortunately the brand equity and the components that affect it are less considered by owners and Officials of football clubs in Iran, especially Persepolis Club, as a club capital and therefore its capacities are not used properly. Of course, paying attention to the brand in our country is a long way from developed countries; Probably because in our country, marketers and company's managers are less aware of the countless benefits of brand equity, and still use the traditional advertising methods for communicating with fans and establishing their brand, and in fact they do not have a correct understanding of concepts such as Brand, its management and brand equity (34).

On the other hand, the clubs existing in the Iranian Premier League, despite their brilliant history and records, such as Persepolis, has lower place in the brand finance football site which ranked 190 clubs throughout the world compared to many clubs in the Asian leagues, including South Korea, Japan, China and Qatar. (35).

Also, the Brand Finance Football site in 2018 in its annual report has considered 3 indicators to determine the power of sports brands, which include brand investment, brand equity and brand performance, and states that in the field of football branding, the future belongs to Football clubs in China (36). Such report indicates that the clubs in the leagues that compete with Iran are working well on its brand equity and will become major powers in football in the near future. In case of having a good understanding of method of its formation and the elements affecting the brand equity of football clubs, it can make desirable plans to enjoy this intellectual capital of clubs. On the other hand, creating brand equity has a great impact on the financial performance of Persepolis Club. For example, Gladen and Millen (1999) stated that a sporting team's product revenue depends on brand equity and in-house success. Biscaia (2015) showed that the loyalty of sports team fans is directly related to brand equity and when fans have more loyalty, they have a more positive consumption behavior towards the team. Therefore, considering the effect of brand equity on revenue generation and financial performance of sports teams, it seems necessary to identify and study the factors affecting brand equity of Persepolis Club as one of the most proud and popular football clubs in Iran. Therefore, the purpose of this study is to answer the question of what is the relationship between brand authenticity and brand equity with the mediating role of brand personality in Persepolis Club?

\section{MATERIALS AND METHODS}

Design. The present research is descriptive and in terms of purpose, it is an applied kind of studies.

Participants. The statistical population of the present research was the fans of Persepolis Football Club and the statistical sample of 410 people (using Cochran's formula and a sufficient number of samples in structural equations modeling) who were selected by available sampling method (Table 1).

Instrument. The method of field data collection was used in the present research that was made through quantitative data collection. A standard questionnaire consisting of four sections was used to collect information. The first section was demographic information (4 questions), the second section was questions related to brand authenticity which brand authenticity questionnaires (Kadirov, 2010) (14 questions) were used for this purpose. The next section was questions related to brand equity, which the standard questionnaire (Kim and Kyoum, 2011) (15 questions) was used in this regard and finally the last section included questions related to brand personality, for which the brand personality questionnaire (Tsiotsou, 2012) (24 questions) was applied. The validity of this questionnaire and its reliability was determined by professors and Cronbach's alpha test (87\%), respectively. 
Table 1. The Demographic Characteristics of Participants in Such Research Are Pointed Out and Listed in

\begin{tabular}{|c|c|c|c|c|c|c|c|c|c|}
\hline \multirow[t]{2}{*}{ Variables } & \multicolumn{5}{|c|}{ Education } & \multicolumn{4}{|c|}{ Age } \\
\hline & $\begin{array}{l}\text { Less than } \\
\text { High } \\
\text { School } \\
\text { Diploma }\end{array}$ & $\begin{array}{c}\text { High } \\
\text { School } \\
\text { Diploma } \\
\text { and } \\
\text { Associate's } \\
\text { Degree }\end{array}$ & $\begin{array}{c}\text { Bachelor's } \\
\text { Degree }\end{array}$ & $\begin{array}{c}\text { Master's } \\
\text { Degree }\end{array}$ & $\begin{array}{l}\text { Ph.D. } \\
\text { Degree }\end{array}$ & $\begin{array}{l}\text { Under } 20 \\
\text { Years old }\end{array}$ & $20-30$ & $31-40$ & $\begin{array}{c}40 \\
\text { Years } \\
\text { of and } \\
\text { Above }\end{array}$ \\
\hline Frequency & 69 & 93 & 135 & 75 & 38 & 94 & 148 & 105 & 63 \\
\hline Percent & 16.8 & 22.6 & 32.9 & 18.2 & 9.2 & 22.9 & 09.36 & 25.6 & 15.3 \\
\hline \multirow[t]{2}{*}{ Variable } & \multicolumn{2}{|c|}{ Marital Status } & \multicolumn{4}{|c|}{ Watcher's Record } & \multicolumn{3}{|c|}{ Amount of Income } \\
\hline & Single & Married & $\begin{array}{c}\text { Less Than } \\
5 \text { Years }\end{array}$ & $\begin{array}{c}5-10 \\
\text { Years }\end{array}$ & $\begin{array}{l}10-15 \\
\text { Years }\end{array}$ & $\begin{array}{c}\text { More } \\
\text { Than } 15 \\
\text { Years }\end{array}$ & $\begin{array}{c}\text { Less } \\
\text { Than } \\
200 \\
\text { Million }\end{array}$ & $\begin{array}{c}2-4 \\
\text { Millions }\end{array}$ & $\begin{array}{c}\text { More } \\
\text { Than } 4 \\
\text { Millions }\end{array}$ \\
\hline Frequency & 283 & 127 & 88 & 196 & 93 & 33 & 230 & 98 & 82 \\
\hline Percent & 69 & 30 & 21.4 & 47.8 & 22.6 & 8.04 & 09.56 & 23.9 & 20.1 \\
\hline
\end{tabular}

Statistical Analysis. In addition, in this research, descriptive statistics were used to describe the demographic status of the respondents and in the inferential statistics section, structural equation modeling was applied. For this purpose, the SPSS and Amos 23 software were utilized.

\section{RESULTS}

In this model (Figure 1), the results indicate a desirable fitness of the variables involved in the structural equation model. In other words, it can be stated that the empirical data supports the theoretical model of the research; Confirmation of this claim refers to the results of Table 2.

In the following, we will consider and review the causal relationships between the variables existing in the model. As can be seen in the above figure, the whole relationships (authenticity and personality on brand equity as well as personality on brand equity), in general, indicate a positive and significant affections.

According to the results of the above (Table 4), it can be said that among the existing variables, brand authenticity on brand equity holds the most impact (0.67) in the form of total effect and personality on brand equity has the lowest impact factor (0.34). Also, the mediating role of brand personality in the causal relationship between the authenticity and brand equity of Persepolis Club was obtained as a partial mediating in a positive and significant direction (0.12).

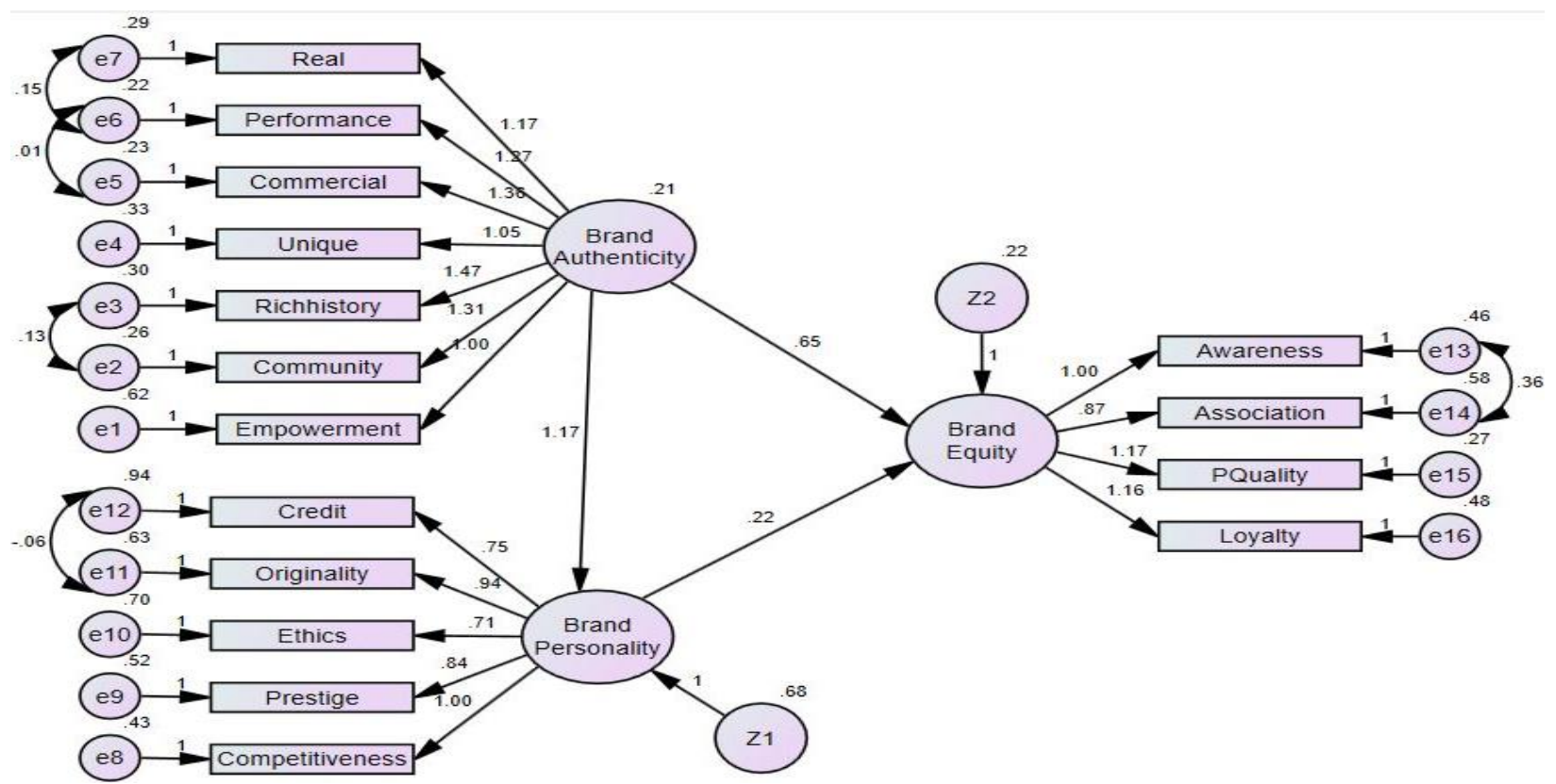

Figure 1. Output of Non- Standard Mode Structural Equations 
Table 2. Results for Evaluation of Model Fitness Indices

\begin{tabular}{lccccccc}
\hline & RMSEA & NFI & TLI & CFI & GFI & RMR & CMIN/DF \\
\hline Values & 0.041 & 0.961 & 0.982 & 0.986 & 0.951 & 0.026 & 1.649 \\
Threshold & 0.08 & 0.90 & 0.90 & 0.90 & 0.90 & 0.05 & 5 \\
\hline
\end{tabular}

Table 3. Standard Error and Critical Ratio in a Table

\begin{tabular}{llccc}
\hline & & & S.E. & C.R. \\
\hline Equity & $<---$ & Authenticity & 0.181 & 6.906 \\
\hline Empowerment & $<---$ & Authenticity & 0.181 & 7.933 \\
\hline Community & $<---$ & Authenticity & 0.2 & 7.951 \\
\hline Rich history & $<---$ & Authenticity & 0.152 & 7.19 \\
\hline Unique & $<--$ & Authenticity & 0.179 & 7.92 \\
\hline Commercial & $<--$ & Authenticity & 0.182 & 8.216 \\
\hline Performance & $<---$ & Authenticity & 0.177 & 8.019 \\
\hline Real & $<---$ & Authenticity & 0.05 & 18.689 \\
\hline Awareness & $<---$ & Equity & 0.056 & 11.778 \\
\hline Association & $<---$ & Equity & 0.064 & 10.122 \\
\hline P Quality & $<---$ & Equity & \\
\hline Loyalty & $<--$ & Equity & & \\
\hline
\end{tabular}

Table 4. Consideration of Causal Relationships between Research Variables

\begin{tabular}{lccc}
\hline Variables & Total Effect & Direct Effect & $\begin{array}{c}\text { Indirect Effect } \\
\text { Significant } \\
\text { Level }\end{array}$ \\
\hline Brand authenticity $\rightarrow$ brand personality & 0.54 & 0.54 & 0.001 \\
Brand authenticity $\rightarrow$ brand equity & 0.67 & 0.45 & 0.12 \\
Brand personality $\rightarrow$ brand equity & 0.34 & 0.34 & 0.001 \\
\hline
\end{tabular}

\section{DISCUSSION}

The aim of this research was to study the effect of brand authenticity on the brand equity of Persepolis Club with the mediating role of brand personality. Brand experts often promote authenticity as a key source of competitive advantage and brand remedy, especially in times of distress and loss of trust. Research findings showed that the brand authenticity of Persepolis Club affects the brand equity. This result of research corresponds with the results of research made by Sajjadi et al. (2013), Torabi (2016), Julie Napoli et al. (2014), Barrio-García \& PradosPeña (2019) and Chieh Lu et.al (2015). BarrioGarcía \& Prados-Peña (2019) stated that brand authenticity affects brand equity (21, 37-40). Also, Sajjadi et al. (2013) stated that from the viewpoint of officials, experts and fans of Tehran Persepolis Football Club, the loyalty of fans, stars, team success, club management, stadium, club history, coach, media, supporters and logo had the greatest impact on brand equity of club, respectively (37). In explanation of this conclusion, it should be noted that authenticity indicates what is real, pure, and without hypocrisy, and is true in terms of superficial and deep features. This definition of authenticity appears well in Persepolis Football Club; because adherence to promises, not pretending and being a favorite of the various groups of watchers and fans can be used for assessing and measuring the brand authenticity of this football club. In fact, Persepolis Club has been able to increase the loyalty to its fans to a high level through the high number of fans and the providing the honest and desirable services (quality competitions) and making the pleasant experiences. It is also a feature of the brand authenticity of the club that has succeeded to create a high level of desire and willingness among fans and watchers to be aware of the special features and qualities of the club, and thus, have a good knowledge of the club brand. In fact, according to the results of this study, in which nearly $83 \%$ of Persepolis fans are academically educated, the understanding of brand authenticity and its impact on the brand equity of Persepolis Club is very tangible.

In other words, Persepolis Football Club holds a genuine brand and therefore can keep away the competitors and rivals away as opportunistic followers and copyists, and thus creates a significant barrier for competition, which is the perceived quality of their brand from the fans and 
other teams. Therefore, it is recommended that the management of Persepolis Club be honest in informing in all aspects and inform the fans as soon as possible. Besides this matter, the history of Persepolis Club is also considered as one of the important structures of brand authenticity. As Kadiro (2010) states, a brand's history and its ability to create communities can promote a brand's authenticity (25). Persepolis team is one of the most rooted teams in Iranian football, and therefore the level of loyalty and association of its football watchers and fans is high, and this matter confirms the significant relationship between the brand authenticity of Persepolis Football Club and its brand equity. Therefore, Persepolis Club can collect all its honors and expose its rich and successful history to its fans. In this regard, it is noteworthy to note that the greatest impact of the components of brand authenticity on brand equity is related to communities. These are the passionate fans who follow the competitions of such team throughout the country and always support their team in all fields and help strengthen and promote their team brand with synergy and empowerment. The results of the descriptive part of the research also confirm that $84 \%$ of the fans of Persepolis club are under 40 years old, which is a relatively young community, so it creates good excitement and communities to support the club. In addition, due to the reputation and rich history of the club, the quality of the competitions and the victories of Persepolis Club play a great role in the perceived quality of their brand. As a matter of fact, the more Persepolis team is able to nationally or internationally achieve ranks, accordingly, the more awareness into this team and its brand association would increase.

Another result of this research was that the brand authenticity of Persepolis Club affects the brand personality. This result of research is consistent with the results of research made by Hernandez Fernandez and Lewis (2019), Portal et.al. (2018), Shirzadi et al. (2015) (23, 41, 42). Hernandez Fernandez and Lewis (2019) state that brand authenticity has a significant relationship with brand trust, which is one of the components of the brand personality of sports teams (23). The result of this research shows that the more a football team brand authenticity is at high level, therefore, the brand of that team will elevate at high rates and it can allocate to itself some more and important aspects. In other words, Persepolis team could be able to bring desirable personality traits to their team brand due to its rich history, being commercial, numerous communities and good performance. In fact, the experience of the fans and watchers with regard to Persepolis brand and their expectations has led them to consider a human aspect (personality) for their team. This brand personality distinguishes their team brand from their competitors or rivals. Two factors of product-related features and mental features are of special importance in distinguishing the brand personality of football clubs. As Aker (1997) states, the product-related features in football teams, including the quality of the game, the quality of the players, competitions holding time, victory, achievements, etc., and mental features such as the mental image that fans have of their favorite team, financial supports made from the teams, advertising style and financial ability of team, famous players and personalities who have been present in team and the that team brand, etc. are considered as the sources of creation and development of the brand personality (26). Bedsides this matter, it should be noted that from the viewpoint of Tsiotsou (2012), five components such as competitiveness, prestige, ethics, originality and credit play an important role in the brand personality of football clubs. Such result represents that the more original and authentic are the clubs, (rich history, extreme performance, being commercial, various communities, empowerment and good performance), therefore, the more favorable human aspects such as competitiveness, prestige, ethics, originality and credit will appear and these affairs will help the club's brand equity altogether and in the form of synergy (28).

In the final model of the research, the relationship between brand personality and brand equity of football clubs is significant from two perspectives. First, the direct relationship that the brand personality of football clubs has with its brand equity. This research was showed that the brand personality of football clubs affects the brand equity. The results of this section correspond with the results of Khandan et al. (2018), Aghazadeh et al. (2016), Darzian et al. (2016), Jin Su, \& Tong (2015) and Xiao Tong et.al. (2017). Khandan et al. (2015) (43-46), in their research entitled "The relationship between brand personality and consumer-based brand equity in the most popular teams selected in the State Premier Football League" showed that there is a positive and significant relationship between 
the whole dimensions of brand personality and brand equity. Jin $\mathrm{Su}, \&$ Tong (2015) also stated that brand personality affects brand equity and can create brand equity. This means that a football club that enjoys the enough personality can create a favorable and desirable awareness and association in the minds of fans and watchers, as well as strengthen and promote their loyalty (45). In fact, the results show that from the viewpoint of the fans, whereas Persepolis football team holds one of the five personality traits such as competitiveness, prestige, ethics, originality or credit, it can strengthen its brand equity. Also, brand personality can cause the symbolic advantages to be created for fans and watchers of football clubs and can be used as a tool to show off and express the personality related to their team brand.

Also, the brand personality of football clubs can help transfer the club features (players, coaches, stadium, style of play, etc.) to the watchers and fans, and in this way, it creates functional advantages such as favorable association with the club brand and more loyalty. In other words, fans view the dimensions of brand personality as added value of the brand, and as Aker (1997) stated, brand personality leads to create a stable image of the brand in the customers' minds, which will affect the behavior of fans and watchers of the football club and their attitudes towards their club brand (26). Therefore, it can be said that creating a top brand personality for football clubs may most likely enhance the brand equity of that club. Second; the indirect relationship that brand personality plays as a mediator between the brand authenticity of football clubs and their brand equity which has been shown in this study, so brand authenticity affects the brand personality of football clubs. This means that whereas football clubs enjoy from rich history, favorable commercial activity, various communities and high performance, they can also acquire a good personality and such chain will be completed by promoting their brand equity. In other words, they can create a high perceived quality in their brand and consequently create a level of loyalty in the fans and watchers.

\section{CONCLUSION}

Therefore, the marketing managers of football clubs shall do their best to improve the experience of the fans and watchers through providing appropriate and timely information with regards the club and its activities. Based on the results, the brand personality can create brand equity for football clubs, the most important of which will be loyalty to football clubs. It should be noted that the brand personality of a football club is not created suddenly and it takes a long time to be formed due to the accumulation of watchers' experience. In the experience of football club's watchers, marketing communication, promotion and social responsibility can be enjoyed to build the club's brand personality desirably and optimally. In addition, the necessity to develop and achieve deep, effective communication methods and work to create and institutionalize the brand personality of football clubs is vital. Finally, considering the effect of brand authenticity and brand personality on the brand equity of Persepolis Club, club managers shall pay special attention to the components of brand authenticity and invest in them. As the results showed, the direct impact of brand originality on brand equity is greater than its indirect impact on brand personality, and this may be due to the fact that Persepolis fans have a better understanding of brand originality and its components such as history. They have communities, business activities and.... And this shows that paying attention to brand originality with the aim of directly increasing brand equity can be more effective. In this regard, it seems that the brand equity of the club can be promoted through the proper management of the fans and paying attention to their demands, attracting valuable stars and maintaining the team's star players, appropriate planning in order to achieve national and continental successes, selection of efficient and expert managers and those who are familiar with the club's issues, proper management in order to build a new and modern stadium or ownership of one of the existing stadiums, adherence to common principles and standards confirmed by the fans, attempting to make appropriate and timely changes, trying to increase the team's competitiveness in different competitions, attempting to introduce the valuable background of the team, implementation of cultural programs in accordance with the brilliant history of the club, interaction with mass media and proper use of modern media, trying to attract prominent and reputable domestic and foreign sponsors and designing proper logo that reflects the values and background of the club.

Such research, like other researches holds some constraint and limitations. A statistical 
population of the study was limited to the fans of Persepolis Club. Therefore, it is proposed that such research be reviewed in other clubs as well. Despite the anonymity of the questionnaire, there were some possible considerations and orientations by the respondents. Also, the aim of this research was to review and study the relationship between brand authenticity and brand equity under the mediating role of brand personality, but in the field of sports, team identity acts as one of the main variables affecting on the watchers' behavior. Thus, it is offered that the moderating role of team identity shall be examined in this regard. Finally, the questionnaire of such research was completed in the second half of 2019. It is suggested that the questionnaire be done according to the changes made in Persepolis club (change of management, technical staff, etc.) at different periods of time.

\section{APPLICABLE REMARKS}

- The brand equity makes the fans loyal.

- The components of brand Authenticity are very important in creating brand personality and brand equity, so Persepolis Club can improve its brand personality and increase brand equity by planning on these components such as history, fan communities, etc.

- It is recommended that Persepolis Club establish its own museum. The establishment of the club museum shows the history and authenticity of the club brand.

- It is recommended that Persepolis Club, by strengthening its fan base, control and guide their communities.

\section{REFERENCES}

1. Kim S, Elisavet Manoli A. Building team brand equity through perceived CSR: the mediating role of dual identification. J Strategic Market. 2020. doi: 10.1080/0965254X.2020.1795912

2. Manoli AE. Brand capabilities in English Premier League clubs. Europe Sport Manage Quarter. 2020;20(1):30-46. doi: 10.1080/16184742.2019.1693607

3. Wang MCH, Tang YY. Examining the antecedents of sport team brand equity: A dual-identification perspective. Sport Manage Rev. 2018;21(3):293-306. doi: 10.1016/j.smr.2017.07.010

4. Kunkel T, Doyle JP, Funk DC. Exploring sport brand development strategies to strengthen consumer involvement with the product - The case of the Australian A-League. Sport Manage Rev. 2014;17:470483. doi: 10.1016/j.smr.2014.01.004

5. Kaynak E, Gulberk G, Ekrem T. An integrative framework linking brand associations and brand loyalty in professional sports. Brand Manage. 2008;15(5):336-357. doi: 10.1057/palgrave.bm. 2550117

6. Rădulescu C, Hudea OS. Econometric modelling of the consumer's behavior in order to develop brand management policies. Econom Res Ekonomska Istraživanja. 2018;31(1):576-591. doi: 10.1080/1331677X.2018.1442232

7. Gutiérrez Rodríguez P, Cuesta Valiño P, Vázquez Burguete JL. The effects of corporate social responsibility on customer-based brand equity: Spanish hypermarket case. Economic ResearchEkonomska istraživanja. 2017;30(1):290-301. doi: 10.1080/1331677X.2017.1305797

8. Hosseini H. Reviewing the influence of the Company Image on Consumer Attitudes towards Brand Expansion (Case Study: providing cellphone services by Apple company), Master's Thesis, University of Tehran, Qom College. 2012.

9. Kim Y, Kyoum T, G. A conceptual framework for understanding relationships between sport consumers and sport organizations: A relationship quality approach. J Sport Manage. 2011;25:57-69. doi: $10.1123 /$ jsm.25.1.57

10. Mahmoud Hosseini M, Abolfazli SA, Rahimi Heleri M. Studying the influence of brand equity on consumer response (Case study: Iranol Company). Perspect Manage J. 2009;32:9-28.

11. Olsen SO. "Comparative evaluation and the relationship between quality, satisfaction, and repurchase loyalty". J Academ Market. 2002. doi: 10.1177/0092070302303005

12.Lin LY. The Relationship of Consumer Personality Trait, Brand Personality and Brand Loyalty: An Empirical Study of Toys and Video Games Buyers. J Product Brand Manage. 2010;19(1):4-17. doi: 10.1108/10610421011018347

13. Aaker DA. Building strong brands.: Simon \& Schuster; 1996.

14. Ahmadvand F. Ahmad SardariReviewing the influence of brand equity on consumers' responses, two scientific-research quarterly journals, Shahed University, 21st year - new volume2014. 
15. Nam J, Ekinci Y, Whyatt G. Brand equity, brand loyalty, and consumer satisfaction. Annal Tourism Res. 2011;38(3):1009-1030. doi: 10.1016/j.annals.2011.01.015

16. Shams Al-Heroudi SH, Kamali Rad E, Derafsh R. Reviewing the Relationship between Brand Equity and Customer Loyalty with respect to the Mediating Role of Competitive Advantage and Customer Satisfactio. Manage Account Stud Quarter J. 2018;4(2):57-70.

17. Aaker DA. Managing Brand Equity: Capitalizing on the Value of a Brand Name, TheFree: Press N.Y; 1991.

18. Gladden JM, Funk DC. "Developing an understanding of brand associations in team sport: empirical evidence from consumers of professional sport". J Sport Manage. 2002;16(1):54-81. doi: $10.1123 /$ jsm.16.1.54

19. Underwood R, Bond E, Baer R. Building service brands via social identity: lessons from the sports marketplace. J Market Theory Pract. 2001;9(1). doi: 10.1080/10696679.2001.11501881

20. Gupta S, Melewar TC, Bourlakis M. Transfer of brand knowledge in business-to-business markets: A qualitative study. J Business Indust Market. 2010;25:395-403. doi: 10.1108/08858621011058151

21.Torabi Sedeh M. Investigating the effect of perceived customer's authenticity on brand choice using loyalty mediating variable, Master's Thesis, Payame Noor University, Karaj Branch.2016.

22. Rumiani M. Designing a Model of influence on Brand authenticity and Brand Equity on loyalty of watchers towards Brands in Iranian Premier Volleyball Club. Case Studies: Volleyball Club of Bank Sarmayeh Tehran. Master's thesis, Faculty of Physical Education and Sports Science, Shahid Rajaee Teacher Training University 2018.

23. Asuncion HF. Collin Lewis Mathieu Brand authenticity leads to perceived value and brand trust. Europe J Manage Business Econom. 2019;28(3):222-238. doi: 10.1108/EJMBE-10-2017-0027

24.Zargham Borujeni H, Barzani H. Pathology of Iran Tourism Brand. Scientific-research quarterly journals of Modern Marketing Research, Third Year, First number2013. 63-80 p.

25. Kadirov D. "Brand Authenticity. Scale Development and Validation2010.

26. Aaker JL. "Dimensions of brand personality". J Market Res. 1997;34:34756. doi: 10.2307/3151897

27. Valette P, Guizani H, Merunka D. The impact of brand equity. J Business Res. 2011;64(1):24-28. doi: 10.1016/j.jbusres.2009.09.015

28. Rodoula T. "Developing a scale for measuring the personality of sport teams". J Servic Market. 2012;26(4):238-252. doi: 10.1108/08876041211237541

29. Freling TH, Forbes L. An empirical analysis of the brand personality effect. J Product Brand Manage. 2005;14(7):404-413. doi: 10.1108/10610420510633350

30. Giroux M, Pons F, Maltese L. "The role of perceived brand personality in promotion effectiveness and brand equity development of professional sports teams". Int J Sport Market Sponsorship. 2017;18(2):180-195. doi: 10.1108/ IJSMS-05-2017-092

31. Freling TH, Crosno J, Henard D. Brand personality appeal: Conceptualization and empirical validation. J Academ Market Sci. 2011;39(3):392-406. doi: 10.1007/s11747-010-0208-3

32. Dimitra P, Kyriaki K, Kostas A, Nikos T. The brand personality of professional football teams, Sport, Business and Management. Int J Sport Market Sponsorship. 2019;9(5):443-459. doi: 10.1108/SBM-032018-0021

33. Muhammad Faisal S, Muhammad B, Jin X, Tahir Y. "Impact of smartphone brand experience on brand equity: With mediation effect of hedonic emotions, utilitarian emotions and brand personality". J Islam Market. 2018. doi: 10.1108/JIMA-04-2017-0045

34.Parhizgar MM, Ebrahimi Abed M. "Studying the effect of brand equity dimensions in Aker model on brand equity from the consumer's viewpoint". J Business Stud. 2012;53:7.

35. The Brand Finance Football 50 2012. Available from: www.Brandfinance.com.

36. The Brand Finance Football 50. The annual report on the most valuable football brands. 2018. Available from: www.Brandfinance.com.

37. Sajjadi SN, Rajabi H, Abedlati M, Tarighi R. Studying the effective factors on the brand equity of Tehran Persepolis Club. New Approach Sport Manage. 2013;1(3):43-52.

38. Napoli J, Sonia J, Dickinson M, B. Beverland, Francis Farrelly. Measur Consumer Based Brand Authenticit. 2014 doi: 10.1037/t62358-000 
39. García Salvador del B, Peña Ma Belén P. Do brand authenticity and brand credibility facilitate brand equity? The case of heritage destination brand extension. J Destinat Market Manage. 2019;13:10-23. doi: 10.1016/j.jdmm.2019.05.002

40. Allan Cheng CL, Dogan G, Yirong Lu C. Authenticity perceptions, brand equity and brand choice intention: The case of ethnic restaurants. Int J Hospital Manage. 2015;50:36-45. doi: 10.1016/j.ijhm.2015.07.008

41. Sivan P, Russell A, Bendixen M. The role of brand authenticity in developing brand trust. J Strategic Market. 2018. doi: 10.1080/0965254X.2018.1466828

42. Shirzadi P, Quchani F. Studying the influence of Brand authenticity on Brand Trust, 2015, 5th National Conference and 3rd International Conference on Accounting and Management with the applied approaches and New Research2015.

43. Khandan N, Atghia N, Mokhtari Dinani M. The Relationship between Brand Personality and ConsumerBased Brand Equity in Popular Teams Selected in the state Premier Football League. Appl Res Sport Manage. 2018;6(4):83-91.

44. Aghazadeh H, Amini Kasbi H, Jafari E. Studying the role of brand personality in the formation of brand equity (Case study of the Hamrahe Aval mobile network). Manage Res Iran. 2016;20(2):1-20.

45. Su J, Tong X. "Brand personality and brand equity: evidence from the sportswear industry". J Product Brand Manage. 2015;24(2):124-133. doi: 10.1108/JPBM-01-2014-0482

46. Tong X, Su J, Xu Y. Brand personality and its impact on brand trust and brand commitment: an empirical study of luxury fashion brands. Int J Fashion Design Technol Educat. 2017. doi: 10.1080/17543266.2017.1378732 